\title{
Kebisingan Di Rumah Sakit Siloam Manado Sebagai Fungsi Jumlah Kendaraan Yang Melewati Jl, Sam Ratulangi Manado
}

\author{
Selfina Levina Ukru a*, Seni H.J. Tongkukut a*, Ferdy a* \\ aJurusan Fisika, FMIPA, Unsrat, Manado \\ KATA K UN C I

\section{A B S TR A K}

Tingkat Kebisingan

Intensitas Bunyi

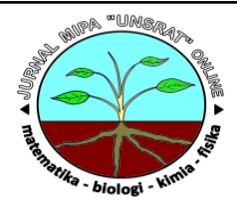

Telah dilakukan penelitian untuk mengukur dan menganalisis tingkat kebisingan yang ada di lingkungan Rumah Sakit Siloam jalan Sam Ratulangi Manado. Pengambilan data dilakukan dengan menggunakan Sound Level Meter DB 200 pada dua lokasi pengukuran (5 titik). Data yang diperoleh adalah nilai tingkat intensitas kebisingan pada masingmasing titik pengukuran. Hasil analisis menunjukkan bahwa tingkat kebisingan tertinggi di lokasi 1 yaitu 74,5 dB dan 59,01 dB untuk lokasi 2. Hasil ini menunjukkan Rumah Sakit Siloam Manado memiliki tingkat kebisingan yang melebihi batas kebisingan yang diperkenankan di Rumah Sakit yaitu sebesar 55 dB Menurut Keputusan Menteri Negara Lingkungan Hidup No. 48 Tahun 1996.

KEYW OR D S

Noise level, Intensity of sound
A B S T R A C T

The Research was conducted to measure and analyze the level of noice in Siloam Hospital at Sam Ratulangi street. The collection of data are made by using the Sound Level Meter DB 200 on two locations of measurement ( 5 points). The result of data is the value level of noise intensity on each measuring point. The analysis show that the highest noise level in the first location is $74.5 \mathrm{~dB}$ and $59.01 \mathrm{~dB}$ for the second location. These results indicate that the noise level of Siloam Hospital Manado exceeds noise limits that are allowed for the hospital equal to 55 $\mathrm{dB}$ according to the decision of the Minister of Environment No. 48 of 1996.
TERSEDIA ONLINE

01 Agustus 2016

\section{Pendahuluan}

Kebisingan adalah bunyi atau suara yang tidak dikehendaki dan dapat mengganggu kesehatan, kenyamanan serta dapat menimbulkan ketulian. Beberapa penelitian yang dilakukan di banyak negara berkembang menyimpulkan bahwa jalan raya merupakan salah satu sumber kebisingan

(Fafiroh, 2013 ). Hal ini disebabkan oleh banyaknya pemakaian kendaraan bermotor, dibandingkan dengan kendaraan lain. Selain itu, peningkatan jumlah kendaraan sebagai sarana transportasi merupakan salah satu faktor yang menyebabkan peningkatan kebisingan. Pada level tertentu suara-suara tersebut masih dapat ditolerir dalam arti bahwa akibat yang ditimbulkannya bukan merupakan suatu gangguan akan tetapi pada tingkat yang lebih tinggi suara yang ditimbulkan oleh kendaraan tersebut sudah merupakan suatu gangguan atau polusi yang disebut kebisingan.

Rumah Sakit Siloam Manado sebagai tempat perawatan terletak di pusat kota dengan arus lalulintas yang ramai, sehingga perlu dilakukan penelitian untuk mengetahui besar tingkat kebisingan di lingkungan rumah sakit. Pengukuran 
bunyi di lakukan dengan menggunakan alat Sound Level Meter DB 200. Penelitian ini diharapkan akan membantu menginformasikan dengan akurat tingkat kebisingan suatu daerah khususnya di Rumah Sakit Siloam dan akan membantu pihak pihak terkait untuk menindaklanjuti dalam pencarian solusi.

\section{Material dan Metode}

\subsection{Bunyi}

Bunyi atau suara, dapat didengar oleh telinga disebabkan oleh bergetarnya selaput telinga karena terkena gelombang longitudinal di udara, yang berasal dari sumber getaran di sekelilingnya. Dengan demikian, bunyi adalah gelombang yang dirambatkan di udara dengan udara berlaku sebagai mediumnya. Biasanya telinga manusia mempunyai kepekaan terhadap rentang bunyi 20$20.000 \mathrm{~Hz}$ sesuai dengan umur dan pertambahan umurnya. Selain rentang frekuensi tersebut, terdapat rentang frekuensi di bawah $20 \mathrm{~Hz}$ yang disebut dengan bunyi infra (infra sounic) dan di atas $20.000 \mathrm{~Hz}$ disebut dengan bunyi ultra (ultra sounic) (Satwiko, 2005).

\subsection{Kebisingan}

Kebisingan dapat dideskripsikan dalam beberapa istilah dari tiga variabel yaitu amplitudo, frekuensi, dan pola waktu. Dari tiga variabel tersebut dapat dijelaskan:

a. Amplitudo, Kerasnya dari suatu bunyi bergantung pada amplitudo dari naik turunya tekanan di atas dan di bawah yang digabungkan dengan gelombang suara.

b. Frekuensi. Suara adalah fluktuasi dari tekanan udara. Bilangan dari terjadinya fluktuasi waktu dalam satu detik disebut frekuensi. Dalam akustik frekuensi dinyatakan dalam satuan hertz $(\mathrm{Hz})$

c. Pola waktu. Karakteristik penting yang ketiga dari kebisingan yaitu variasi dalam waktu.

\subsection{Bising Lalu Lintas}

Sumber kebisingan lalu lintas termasuk dalam kriteria kebisingan garis. Kebisingan tersebut ditimbulkan oleh suara-suara dari kendaraan bermotor yang melewati jalanan karena semakin padatnya lalu lintas yang ada di jalan tersebut. Adapun penyebab kebisingan dari kendaraan bermotor seperti yang sudah dijelaskan di atas adalah mesin dari kendaraan bermotor itu sendiri yang biasanya berjenis mesin bakar, jenis kipas pendingin kendaraan, bagian sistem pembuangan kendaraan yang berbeda-beda, dan model kendaraan. Selain penyebab kebisingan dari kendaraan tersebut, ada pula parameter dari kendaraan itu sendiri yaitu kecepatan dan kepadatan kendaraan bermotor yang ada di lalu lintas jalan, komposisi kendaraan bermotor tersebut, sifat dari pengemudi kendaraannya sendiri, dan kestabilan atau ketidakstabilan lalu lintas kendaraan bermotor.

Berikut baku tingkat Kebisingan yang diizinkan Menurut Keputusan Menteri Negara Lingkungan Hidup No. 48 Tahun 1996

1. Rumah Sakit $55 \mathrm{~dB}$

2. Sekolah atau $55 \mathrm{~dB}$

3. Tempat Ibadah $55 \mathrm{~dB}$

\subsection{Metode Penelitian}

Penelitian dilakukan di lingkungan Rumah Sakit Siloam dengan menggunakan Sound Lever Meter DB 200, Stopwatch dan alat penghitung kendaraan bermotor. Pengambilan data di lakukan di dua area yaitu lokasi 1 di daerah sekitar lantai-1 Rumah Sakit pada titik 1, titik 2 dan titik 3 dan lokasi 2 di daerah perawatan di lantai -2 pada titik 4 dan titik 5. Data yang diperoleh adalah nilai tingkat bising sinambung ekivalen ( Leq) pada masing-masing titik yang telah ditentukan.

Dalam penelitian ini, langkah-langkah yang dilakukan untuk mencapai tujuan penelitian adalah melakukan pengukuran di tiap-tiap titik sehingga didapatkan masing-masing nilai tingkat bising sinambung equivalen (Leq) selama sepuluh menit. Pengukuran dilakukan selama 1 jam dengan pembacaan data tiap 1 menit yang kemudian dirataratakan setiap sepuluh menit. Pengukuran di mulai jam 07.00 - 08.00 pagi, jam 12.00 - 13.00 siang dan jam 17.00-18.00 sore. Perhitungan jumlah kendaraan yang lewat di Jl. Sam Ratulangi juga di lakukan bersamaan dengan pengukuran kebisingan di setiap titik. Data jumlah kendaraan nantinya akan dikorelasikan dengan data tingkat kebisingan

\section{Hasil dan Pembahasan}

Pengukuran tingkat kebisingan di lokasi 1 pada titik 1, titik 2 dan titik 3 diberikan dalam Leq ratarata tiap sepuluh menit untuk pengukuran pada jam 07.00-08.00, jam 12.00-13.00 dan jam 17.0018.00 diberikan dalam Gambar 4.5

Pengukuran tingkat kebisingan di lokasi 2 pada titik 4 dan titik 5 diberikan dalam Leq ratarata tiap sepuluh menit untuk pengukuran pada jam 07.00-08.00, jam 12.00-13.00 dan jam 17.0018.00 diberikan dalam Gambar 4.6

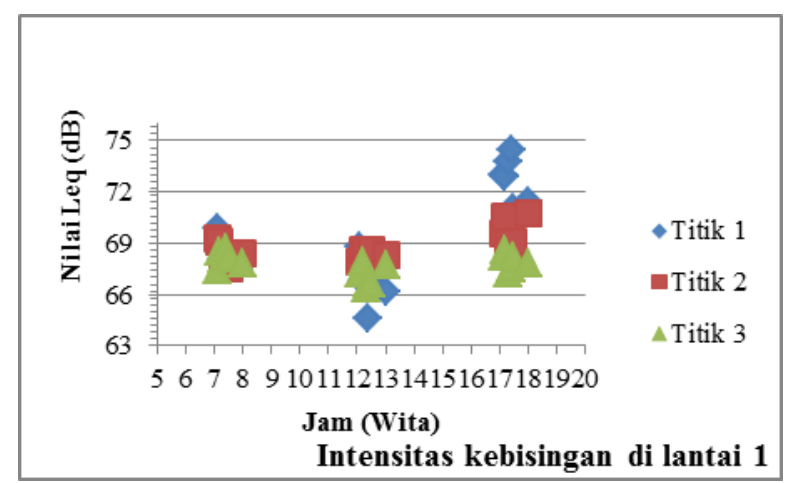

Gambar 1. Grafik hubungan Leq terhadap waktu pada lokasi 1 
Gambar 1 Menunjukan hasil pengukuran tingkat kebisingan pada lokasi 1 titik 1 menunjukan pada jam 12.40 menit tingkat kebisingan yaitu $64.57 \mathrm{~dB}$, dan naik pada 17.40 menit yaitu sebesar $74.5 \mathrm{~dB}$. Lokasi 1 titik 2 yang bertanda warna merah, menunjukan pada jam 07.50 menit tingkat kebisingan yaitu $67.54 \mathrm{~dB}$ dan naik pada jam 18.00 WiTA yaitu sebesar $70.74 \mathrm{~dB}$. Lokasi 1 titik 3 yang bertanda warna hijau menunjukan pada jam 17.40 menit tingkat kebisingan yaitu $68.73 \mathrm{~dB}$, sedangkan pada jam 12.30 tingkat kebisingan menurun menjadi $66.37 \mathrm{~dB}$ dan naik kembali menjadi 68.56 dB pada jam 17.20 menit.

Pengukuran yang sama dilokasi 2 pada titik 4 dan titik 5 diberikan pada Gambar 2

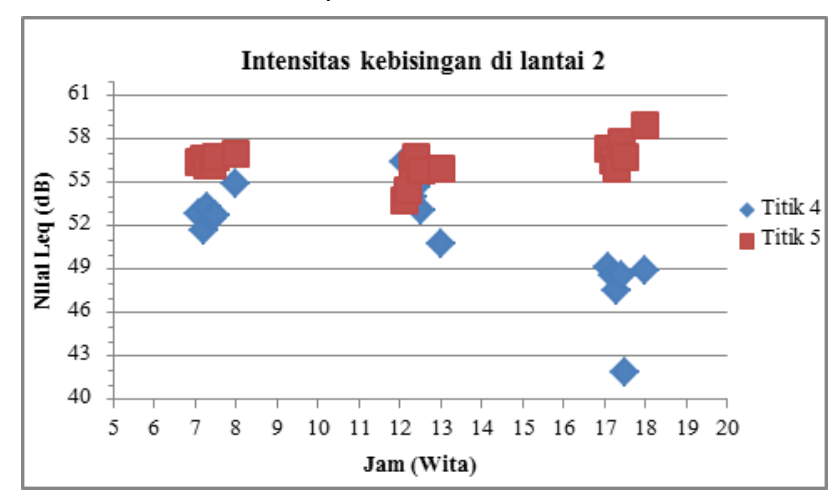

Gambar 2 Grafik hubungan Leq terhadap waktu pada lokasi 2

Gambar 2 Menunjukan hasil pengukuran tingkat kebisingan pada lokasi 2 titik 4 yang bertanda warna biru terlihat tingkat kebisingan rendah pada jam 17.50 menit yaitu $41.9 \mathrm{~dB}$, dan naik kembali pada 12.10 menit yaitu sebesar 56.47 $\mathrm{dB}$ sehingga melebihi batas ambang yang di tentukan. Lokasi 2 titik 5 yang bertanda warna merah, terlihat tingkat kebisingan rendah pada jam 12.10 yaitu $53.75 \mathrm{~dB}$ dan naik kembali pada jam 18.00 WiTA yaitu sebesar $59.01 \mathrm{~dB}$.

Kebisingan maksimum dari pengukuran yang terlihat pada gambar 3 yaitu sebesar $59.01 \mathrm{~dB}$ pada lokasi 2 titik 5 atau pada grafik yang bertanda warna merah. Nilai tersebut di ambil pada pada jam 18.00 WITA, sedangkan kebisingan minimum sebesar 41.9 dB pada jam 17.50 menit di lokasi 2, titik 4 atau pada grafik yang bertanda warna biru.

Perhitungan jumlah kendaraan yang dilakukan bersamaan dengan pengukuran kebisingan lokasi 1 diberikan dalam Gambar 4.7

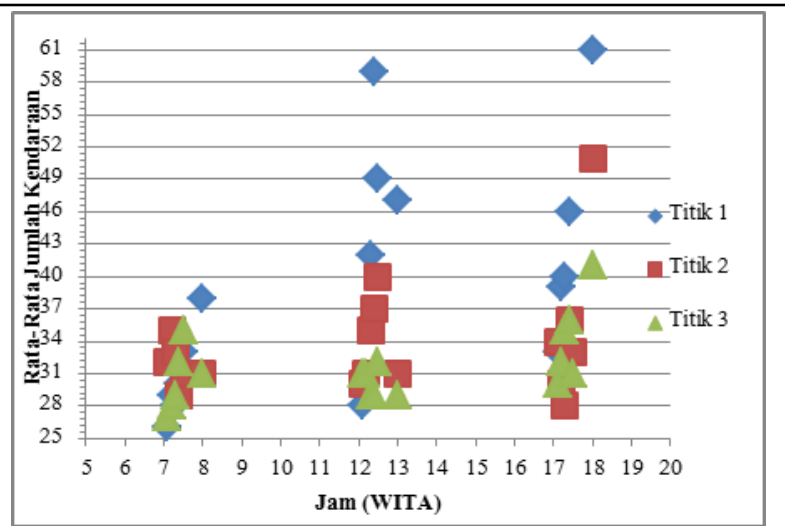

Gambar 3 Jumlah rata-rata kendaraan pada lokasi 1

Nilai rata-rata kendaraan tiap sepuluh menit pada lokasi 1 titik 1 yang bertanda warna biru, terlihat rendah pada jam 07.10 menit yaitu 26 dan naik pada jam 18.00 yaitu sebesar 61. Pada lokasi 1 titik 2 yang bertanda warna merah terlihat rendah pada jam 17.30 yaitu 28 dan naik menjadi 51 pada jam 18.00 WITA. Pada lokasi 1 titik 3 yang bertanda warna hijau terlihat rendah pada jam 07.10 menit yaitu 27 dan naik menjadi 41 pada jam 18.00 WITA.

Jumlah rata-rata kendaraan pada lokasi 1 yaitu sebesar 61 terlihat pada titik 1 atau pada grafik yang bertanda warna biru. Nilai tersebut diambil dari jam 18.00 WITA. sedangkan nilai rata-rata kendaraan rendah yaitu 26 terlihat pada titik 1 diambil dari jam 07.10 menit.

Perhitungan jumlah kendaraan yang dilakukan bersamaan dengan pengukuran kebisingan di lokasi 2 diberikan dalam Gambar 4

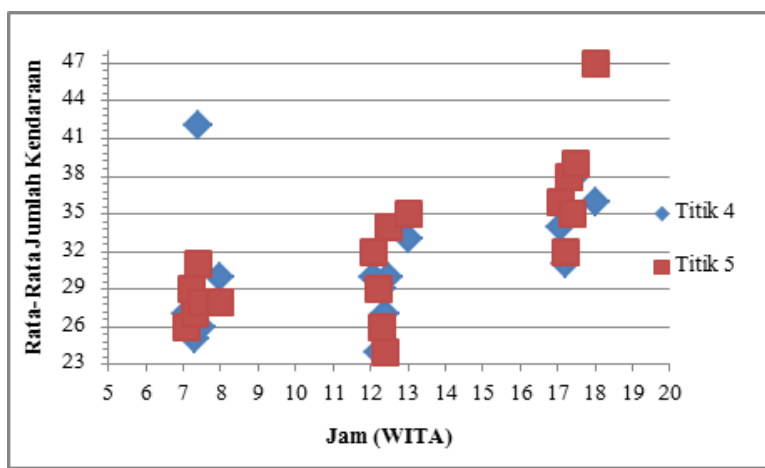

Gambar 4 Nilai Rata-rata kendaraan pada lokasi 2

Nilai rata-rata kendaraan pada lokasi 2 titik 4 yang bertanda warna biru terlihat rendah pada jam 12.20 menit yaitu 24 dan naik menjadi 42 pada jam 07.40 menit. Pada lokasi 2 titik 5 terlihat menurun pada jam 12.30 menit yaitu 26 dan naik menjadi 47 pada jam 18.00 WITA.

Nilai rata-rata kendaraan pada lokasi 2 yaitu sebesar 47 pada titik 5, pada jam 18.00 WITA, sedangkan nilai minimum kendaraan pada lokasi 2 yaitu 24 pada titik 4, pada jam 12.20 menit. Gambar 4.5, 4.6, 4.7 dan 4.8 menunjukan bahwa tingkat kebisingan yang tinggi disertai juga oleh jumlah kendaraan yang tinggi. 
Perbandingan nilai tingkat kebisingan lokasi 1 dan lokasi 2 masing-masing pada titik dengan nilai Leq tertinggi ( lokasi 1 titik 1 dan lokasi 2 titik 5) diberikan dalam Gambar 5

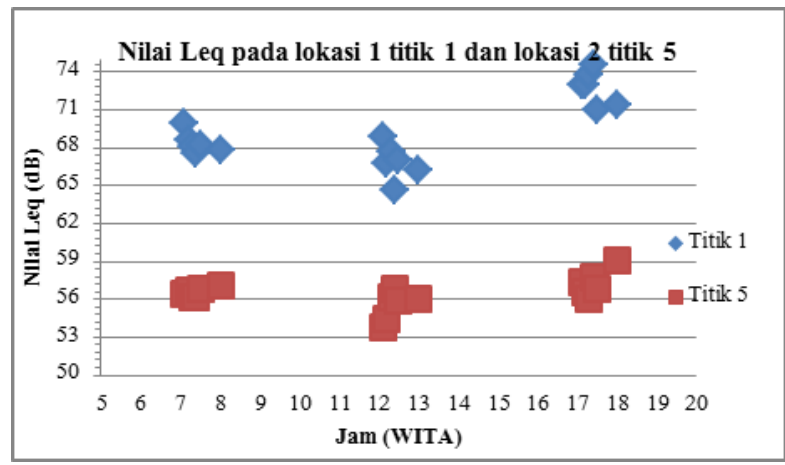

Gambar 5 Perbandingan Nilai Leq pada lokasi 1 titik 1 dan lokasi 2 titik 5

Gambar 5 Menunjukan tingkat kebisingan di lokasi 2 titik 5 lebih rendah di bandingkan lokasi 1 titik 1 . Hal ini karena lokasi 2 berada pada posisi yang lebih jauh dari sumber kebisingan yaitu jalan raya.

Selanjutnya ditunjukan grafik tingkat kebisingan yang diberikan bersama dengan jumlah kendaraan sebagai sumber kebisingan, masingmasing pada perhitungan rata-rata satu jam pengukuran. Grafik diberikan untuk pengukuran kebisingan pada titik 1 dan titik 5 .

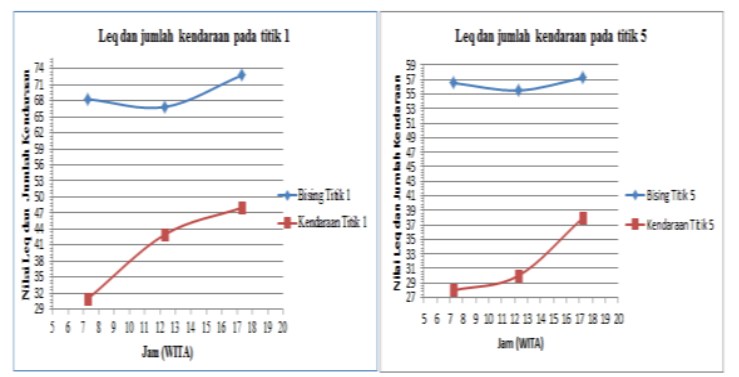

Gambar 6 Grafik tingat kebisingan dan jumlah kendaraan rata-rata dalam satu jam pengukuran

Data dalam bentuk grafik pada Gambar 6 kemudian dilakukan perhitungan korelasi antara tingkat kebisingan dan jumlah kendaraan untuk mengetahui tingkat kebergantungan antara variabel tingkat kebisingan terhadap jumlah kendaraan. Di peroleh hasil bahwa titik 1 korelasi $r$ bernilai 0.54 yang berarti kedua variabel mempunyai hubungan pada tingkat sedang, sedangkan pada titik 5 korelasi $r$ bernilai 0.68 yang berarti variabel mempunyai hubungan yang kuat. Hal tersebut menunjukan bahwa jumlah kendaraan mempunyai kontribusi yang signifikan pada tingkat kebisingan yang terukur di Rumah Sakit Siloam.

\section{Kesimpulan}

Berdasarkan hasil penelitian yang telah dilakukan, di lingkungan Rumah Sakit Siloam Manado yang berdekatan dengan Jl. Sam Ratulagi Manado dapat disimpulkan bahwa

1. Tingkat kebisingan tertinggi rata-rata di dua lokasi pengambilan data, masing-masing adalah sebesar $74.5 \mathrm{~dB}$ untuk lokasi 1, dan $59.01 \mathrm{~dB}$ untuk lokasi 2. Nilai tersebut menunjukan kebisingan di Rumah Sakit Siloam Manado telah melebihi batas ambang yang ditentukan yaitu sebesar $55 \mathrm{~dB}$.

2. Bunyi yang dihasilkan oleh kendaraan bermotor yang melewati jl. Sam Ratulangi memberikan konstribusi besar pada kebisingan di Rumah Sakit Siloam Manado.

\section{Daftar Pustaka}

Suroto, W. 2010.Dampak Kebisingan Lalu Lintas Terhadap Pemukiman Kota (Kasus Kota Surakarta).Jurnal of Rulan and Development.Volume 1, No. 1 Februari 2010

Umiati, S. 2011. Pengaruh Tata Hijau Terhadap Tingkat Kebisingan Pada Perumahan Jalan Ratulangi Makassar.Teknika 2. 2011. 12-19.

Zeamansky, M., dan Sears, F. W. 1999. Fisika Untuk Universitas 1 (Mekanika, Panas, dan Bunyi). Jakarta: Penerbit Trimitra Mandiri.

Buchari.2007. Kebisingan Industri dan Hearing Conservation Program. USU

Repository: Universitas Sumatera Utara.

Djalante, S. 2010. Analisis Tingkat Kebisingan Di Jalan Raya Yang Menggunakan. Alat Pemberi Isyarat Lalu Lintas (APIL) (Studi Kasus: Simpang Ade Swalayan). Jurnal SMARTek. Vol. 8 No. 4. November 2010: 280-300.

Prasasto Satwiko. 2008. Fisika Bangunan, Penerbit ANDI Yogyakarta.

Anza Hana Fafiroh.2013. Pengukuran Tingkat Kebisingan Di Lingkungan SMPN 2 Jember.

Satwiko, P. 2004. Fisika Bangunan 2 (edisi 1). Yogyakarta: Penerbit ANDI.

Menteri Lingkungan Hidup. 1996. Tentang: Baku Kebisingan. Surat Keputusan Menteri Lingkungan Hidup Nomor: Kep48/MENLH/1996/25 November 1996. Jakarta.

Satwiko, P. 2005. Fisika Bangunan 1 (edisi 2). Yogyakarta: Penerbit ANDI. 